\title{
NOTE
}

\section{Comparison between the Thyrotropin Response to Thyrotropin-Releasing Hormone in Summer and That in Winter in Normal Subjects}

\author{
NORIMICHI KONNO \\ Department of Medicine, Hokkaido Central Hospital for \\ Social Health Insurance, Nakanoshima, Sapporo 062, Japan
}

\begin{abstract}
Synopsis
A comparison was made between the thyrotropin (TSH) response to $500 \mu \mathrm{g}$ thyrotropin-releasing hormone (TRH) in summer and that in winter in ten healthy normal adults living in Supporo. The serum resin triiodothyronine $\left(T_{3}\right)$ uptake $\left(R_{3} U\right)$, thyroxine $\left(\mathrm{T}_{4}\right)$ and $\mathrm{T}_{3}$ levels were also measured. While the TSH response to TRH in summer was similar to that in winter, serum $T_{3}$ concentration and free $T_{3}$ index were significantly higher in winter than in summer, associated with the similar values in $\mathrm{RT}_{3} \mathrm{U}$ and $\mathrm{T}_{4}$ levels in serum. Independently measured 86 specimens ( 43 in summer and 43 in winter) from normal adults living in the same district also showed a significant increase in serum free $T_{3}$ index as well as a slight elevation of serum $T_{3}$ concentration in winter but not in serum $\mathrm{T}_{4}$ level. These results indicate that the primary change in cold winter would be the stimulation of peripheral conversion of $\mathrm{T}_{4}$ to $T_{3}$ rather than the activation of hypothalamo-pituitary-thy roid axis. The relevance of this interpretation was discussed.
\end{abstract}

It is generally accepted that thyroid hormone has an important role for nonshivering thermogenesis in cold acclimation (Smith and Hoijer, 1962; Hoch, 1974). Early studies in normal adults in various regions of the world have shown a seasonal variation of serum thyroid hormone concentrations (Oshiba et al., 1957; Watanabe et al., 1963; DuRuisseau, 1965; Nagata et al., 1976; Smals et al., 1977). The elevation of serum thyroid hormone concentration during winter has been interpreted in this way that it is because the pituitarythyroid axis is activated by prolonged cold exposure, thereby secreting more thyroid hormone, but no data are available to prove the concomitant rise of serum thyroid-stimu lating hormone (TSH) concentration during winter (Hedstrand and Wide, 1973; Rastogi

Received April 27, 1978. and Sawhney, 1976; Nagata et al., 1976). In this communication, a study was undertaken to compare the TSH response to thyrotropin-releasing hormone (TRH) in summer with that in winter, in normal adults living in Sapporo, the northern part of Japan. The seasonal variation of serum thyroid hormone concentration was also investigated.

\section{Materials and Methods}

Ten healthy subjects ( 7 male and 3 female) living in Sapporo $\left(43^{\circ} 03^{\prime} \mathrm{N}, 141^{\circ} 20^{\prime} \mathrm{E}\right.$ ), aged 21 to 64 , participated in this study. None of them had either historical or physical findings of any endocrine-metabolic disorders. No special restrictions were made on their physical activity, food intake, clothing and climate conditioning. Blood specimens were obtained in the morning after overnight fast both in summer (July or August) and in winter (January or February) and sera obtained were stored at $-20^{\circ} \mathrm{C}$ until used. Synthetic TRH (Tanabe Pharmaceutical Co.) $500 \mu \mathrm{g}$ 
was given iv as a single bolus between 0900 and $1000 \mathrm{hr}$ and blood sample for TSH was drawn at $0,15,30,60$ and $120 \mathrm{~min}$. after injection. Measurements of serum triiodothyronine $\left(\mathrm{T}_{3}\right)$ and $\mathrm{TSH}$ by radioimmunoassay were made simultaneously for both. summer and winter samples.

86 serum specimens from normal adults were also included as the laboratory control, in which 43 specimens (22 male, 21 female, mean age: 36 ) were obtained in July or August, 1976 and 43 specimens (23 male, 20 female, mean age : 34 ) in January or February 1977. Measurements of serum resin $\mathrm{T}_{3}$ uptake $\left(\mathrm{RT}_{3} \mathrm{U}\right)$, thyroxine $\left(\mathrm{T}_{4}\right)$ and $\mathrm{T}_{3}$ of these specimens were taken on each occasion.

The mean ambient temperature obtained from the official weather station in Sapporo was $-7.5^{\circ} \mathrm{C}$ $-5.5^{\circ} \mathrm{C}$ in winter and $20.3^{\circ} \mathrm{C}-21.3^{\circ} \mathrm{C}$ in summer.

Serum $\mathrm{T}_{4}$ and $\mathrm{RT}_{3} \mathrm{U}$ were measured by Tetrasorbkit and Triosorb-kit respectively (Abbott Laboratories). Serum TSH was measured by double antibody radioimmunoassay using the test kit (HTSH-kit, Daiichi RI Laboratories). Serum $\mathrm{T}_{3}$ was measured by radioimmunoassay using the test kit $\left(T_{3}\right.$ RIA kit, Dainabot RI Laboratories), in which bound and free antigen were separated by the dextran-coated charcoal method. The minimum detectable amount and precision of assay were described elsewhere (Konno, 1976). Free $T_{4}$ index and free $T_{3}$ index were calculated as previously described (Konno, 1974). The same control serum was always processed simultaneously and between-assay coefficients of variation in summer and in winter were as follows; $\mathrm{T}_{4}: 7.7$ $\pm 0.5 \mu \mathrm{g} / \mathrm{d} l(6.5 \%)$ in summer and $7.6 \pm 0.5 \mu \mathrm{g} / \mathrm{d} l$ $(6.6 \%)$ in winter, $\mathrm{T}_{3}: 132 \pm 13 \mathrm{ng} / \mathrm{d} l(9.6 \%)$ in summer and $122 \pm 10 \mathrm{ng} / \mathrm{d} l(8.2 \%)$ in winter, $\mathrm{RT}_{3} \mathrm{U}: 31.3$ $\pm 0.7 \%(2.2 \%)$ in summer and $30.1 \pm 1.9 \%$ (6.3\%) in winter, $\mathrm{TSH}: 7.7 \pm 0.5 \mu \mathrm{U} / \mathrm{ml}(6.5 \%)$ in summer and $7.6 \pm 0.5 \mu \mathrm{U} / \mathrm{m} l(6.6 \%)$ in winter.

For statistical analysis, Student's $t$ test was used and in 10 subjects paired analysis was attempted.

\section{Results}

Serum $\mathrm{RT}_{3} \mathrm{U}, \mathrm{T}_{4}$ and free $\mathrm{T}_{4}$ index values in 10 normal subjects were almost the same both in summer and in winter (Table 1). The values of the laboratory control, measured on the same occasion, also showed no seasonal changes in $\mathrm{RT}_{3} \mathrm{U}, \mathrm{T}_{4}$ and free $T_{4}$ index in serum. Serum $T_{3}$ concentration in 10 subjects was significantly higher in winter than in summer: $195 \pm 34 \mathrm{ng} / \mathrm{d} l$ (mean \pm S.D.) vs $154 \pm 40 \mathrm{ng} / \mathrm{d} l(\mathrm{p}<0.001)$. The elevation of serum $T_{3}$ concentration was seen in all subjects studied and the calculated free $T_{3}$ index was also significantly increased in winter compared with that in summer: $185 \pm 24$ vs $154 \pm 22(\mathrm{p}<$ 0.001 ). The difference in serum $T_{3}$ concentration of the laboratory control was not statistically significant between two seasons, but the calculated normal range in summer and winter was $90-220 \mathrm{ng} / \mathrm{d} l$ and $100-230$ $\mathrm{ng} / \mathrm{d} l$, respectively. Free $\mathrm{T}_{3}$ index in summer was $155 \pm 28$ and $168 \pm 29$ in winter, the difference between the two values being statistically significant $(\mathrm{p}<0.05)$.

TSH response to $500 \mu \mathrm{g}$ TRH was examined in 10 normal adults and the similar pattern of response was observed between two seasons (Fig. 1). Basal TSH concentration was $2.2 \pm 0.4 \mu \mathrm{U} / \mathrm{m} l$ in summer and $1.9 \pm 0.4 \mu \mathrm{U} / \mathrm{m} l$ in winter and the peak value of TSH after TRH in summer and

Table 1. Comparison of serum resin triiodothyronine $\left(T_{3}\right)$ uptake $\left(R_{3} U\right)$, thyroxine $\left(T_{4}\right)$, $T_{3}$, free $T_{4}$ index and free $T_{3}$ index between in summer and in winter in 10 normal subjects and 86 laboratory control specimens.

\begin{tabular}{|c|c|c|c|c|c|c|}
\hline subjects & season & $\mathrm{RT}_{3} \mathrm{U}(\%)$ & $\mathrm{T}_{4}(\mu \mathrm{g} / \mathrm{d} l)$ & $\mathrm{T}_{3}(\mathrm{ng} / \mathrm{d} l)$ & free $T_{4}$ index & free $T_{3}$ index \\
\hline \multirow{2}{*}{10} & summer & $* 31.0 \pm 4.5$ & $9.0 \pm 1.0$ & $154 \pm 40$ & $9.3 \pm 1.9$ & $154 \pm 22$ \\
\hline & winter & $29.4 \pm 4.3$ & $9.5 \pm 1.8$ & $195 \pm 34$ & $9.3 \pm 2.2$ & $185 \pm 24$ \\
\hline $\mathrm{p}^{* *}$ & & ns & ns & $\mathrm{p}<0.001$ & ns & $\mathrm{p}<0.001$ \\
\hline \multicolumn{7}{|c|}{ Laboratory control } \\
\hline 43 & summer & $30.2 \pm 2.7$ & $9.4 \pm 1.5$ & $153 \pm 32$ & $9.5 \pm 1.4$ & $155 \pm 28$ \\
\hline 43 & winter & $30.1 \pm 3.0$ & $9.2 \pm 1.4$ & $168 \pm 36$ & $9.2 \pm 1.3$ & $168 \pm 30$ \\
\hline $\mathrm{p}$ & & ns & ns & $0.05<\mathrm{p}<0.1$ & ns & $\mathrm{p}<0.05$ \\
\hline
\end{tabular}




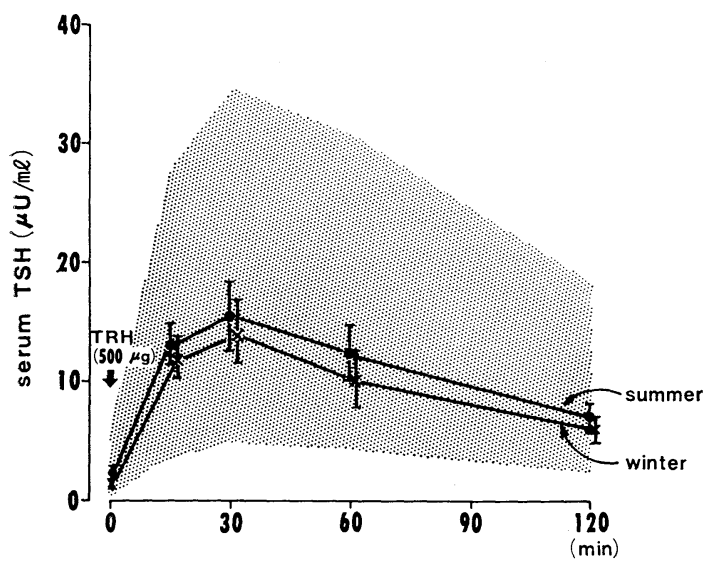

Fig. 1. Serum TSH response to TRH in normal subjects in summer and in winter. TRH-test in 10 normal subjects was performed in summer (July or August, 1976) and in winter (January or February, 1977). Values are expressed as mean \pm SEM. Shaded area encompasses the normal range of response.

in winter was $15.2 \pm 3.1 \mu \mathrm{U} / \mathrm{m} l$ and $14.1 \pm$ $2.8 \mu \mathrm{U} / \mathrm{m} l$, respectively. Mean maximal TSH increments after TRH $(\Delta \mathrm{TSH})$ were $13.0 \mu \mathrm{U} / \mathrm{m} l$ in summer and $12.7 \mu \mathrm{U} / \mathrm{m} l$ in winter. The difference of $\triangle \mathrm{TSH}$ between two seasons was $4.1 \pm 3.1 \mu \mathrm{U} / \mathrm{m} l$ (range, $0.1-8.5 \mu \mathrm{U} / \mathrm{m} l)$.

\section{Discussion}

The present study demonstrated that normal adults living in Sapporo showed a serum $\mathrm{T}_{3}$ concentration significantly higher in winter than in summer, whereas TSH responsiveness to TRH as well as serum $\mathrm{T}_{4}$ concentration was similar between two seasons. Simultaneous measurement of $\mathrm{RT}_{3} \mathrm{U}$ failed to show any seasonal changes, indicating that serum free- $\mathrm{T}_{3}$ concentration was also elevated during winter as reflected by the increase in free- $\mathrm{T}_{3}$ index (Konno, 1974).

Although several investigators reported a winter-related evelation of serum thyroid hormone concentration, there is a disagree- ment whether this occurred in either serum $\mathrm{T}_{4}$ or $\mathrm{T}_{3}$ or in both $\mathrm{T}_{4}$ and $\mathrm{T}_{3}$ : elevation of PBI (Oshiba et al., 1957; Watanabe et al., 1963; DuRuisseau, 1965), elevation of both $\mathrm{T}_{4}$ and $\mathrm{T}_{3}$ (Smals et al., 1977) or of $\mathrm{T}_{3}$ only (Nagata et al., 1976). The reasons for these differences are uncertain. The present results are in agreement with the data of Nagata et al. were obtained in normal subjects in Kajimadaira where the ambient temperatures in summer and in winter are comparable to those in Sapporo, although the climate conditioning is markedly different. It was also confirmatory that the independently obtained values of the laboratory control in our hands showed a slightly higher normal range of serum $T_{3}$ concentration and a significantly elevated free- $T_{3}$ index in winter.

It is well known that the acute cold exposure of experimental animals evoked a brief elevation of serum TSH concentration (Bottari, 1957; Itoh et al., 1966; Konno and Koseki, 1967; Yamada et al., 1965; Hefco et al., 1975; Tal et al., 1976). Even in prolonged exposure to cold, TSH elevation was transient, followed by a return toward the basal level (Itoh et al., 1966; Hefco et al., 1975). Most studies in human adults, on the contrary, failed to find not only the brief elevation of the serum TSH level by acute body cooling (Odell et al., 1967 ; Golstein-Golaire et al., 1970 ; Hershman et al., 1970; Fisher et al., 1971) but also any seasonal changes in serum TSH concentration despite the elevated serum or urinary thyroid hormone concentrations (Hedstrand and Wide, 1973; Rastogi and Sawhney, 1976; Nagata et al., 1976). Although only one dose of TRH $(500 \mu \mathrm{g})$ was tested in the present study, the similar TSH response to TRH both in summer and in winter also indicated that the TSH secretory responsiveness of the pituitary to TRH remained unchanged in winter despite the elevated serum $\mathrm{T}_{3}$ concentration.

Since a small amount of TSH produces 
an increase of serum $\mathrm{T}_{3}$ concentration but not $\mathrm{T}_{4}$ (Snyder and Utiger, 1973; Rabello et al., 1974), it would be possible that the elevation of $T_{3}$ in winter might be produced by the minor and gradual increase in serum TSH which was unassessable by the present radioimmunoassay method.

It has been shown that only minimum changes in serum thyroid hormone concentration, still within the normal range, sensitively affect the TSH response to TRH (Synder and Utiger, 1972; Vagenakis et al., 1974). Hefco et al., in their studies on the effect of acute exposure of rats to cold, suggested that in vivo pituitary responsiveness to TRH was determined by the serum thyroid hormone concentration rather than the pituitary TSH content (Hefco et al., 1975). Chopra et al. proposed that serum $\mathrm{T}_{4}$ but not $\mathrm{T}_{3}$ would be the determinant of TSH secretion (Chopra et al., 1973). This proposal was supported by Sawin et al., who showed a significant inverse relation between peak TSH after TRH and serum $T_{4}$ but not $T_{3}$ in normal subjects (Sawin and Hershman, 1976). In view of these findings, the similarity between TSH response to TRH in summer and that in winter, in the present study, may be expected from the similarity between the serum $\mathrm{T}_{4}$ concentration in two seasons. Therefore, it is probable that the elevation of serum $\mathrm{T}_{3}$ concentration in winter would neither result in an inhibition of TSH response to TRH nor result from the preferential secretion of $T_{3}$ from the thyroid.

The possible cause of increased serum $\mathrm{T}_{3}$ concentration in winter would be the stimulation of peripheral conversion from $\mathrm{T}_{4}$. Bernal et al. reported that the acclimation to cold environment of thyroidectomized rats maintained on a constant dose of $\mathrm{T}_{4}$ induced the increased conversion of $\mathrm{T}_{4}$ to $\mathrm{T}_{3}$ (Bernal et al., 1975). A similar study is in progress in our laboratory with the primary hypothyroid patients receiving a constant dose of $T_{4}$. Preliminary results show an elevation of serum $T_{3}$ concentration during winter associated with significant decrease in serum free- $T_{4}$ index level (unpublished observation). These results may be compatible with the idea that the activation of peripheral conversion of $\mathrm{T}_{4}$ to $\mathrm{T}_{3}$ occurs primarily in winter. This process, if in operation, is to compensate the cold by increasing the basal metabolic rate.

\section{Acknowledgement}

The author is grateful to Professor T. Hiroshige (Department of Physiology, Hokkaido University School of Medicine) for his advice and critical review of this manuscript. The expert technical assistance of Miss K. Nakagawa, Mr. H. Taguchi, Mr. R. Minami and Mr. K. Hagiwara is gratefully acknowledged.

\section{References}

Bernal, J. and F. Escobar del Rey (1975). Acta Endocrinol. (Kbh.) 78, 481.

Bottari, P. M. (1957). Ciba Found. Colloq. Endocrinol. 11, 52.

Chopra, I. J., D. H. Solomon and G. N. C. Teco (1973). J. Clin. Endocrinol. Metab. 36, 1050.

DuRuisseau, J. P. (1965). ibid. 25, 1513.

Fisher, D. A. and W. D. Odell (1971). ibid. 33, 859. Golstein-Golaire, J., L. Vanhaelst, O. D. Bruno, R. Leclercq and G. Copinschi (1970). J. Appl. Physiol. $29,622$.

Hedstrand, H. and L. Wide (1973). Brit. Med. J. 17,420 .

Hefco, E., L. Krulich, P. Illner and P. R. Larsen (1975). Endocrinology 97, 1185.

Hershman, J. M., D. G. Read, A. L. Bailey, V. P. Norman and T. B. Gibson (1970). J. Clin. Endocrinol. Metab. 30, 430.

Hock, F. L. Handbook of Physiol. (edited by M. A. Greer and D. H. Solomon) Section 7, Endocrinol. Vol. III, Thyroid p. 391. (1974).

Itoh, S., T. Hiroshige, T. Koseki and Nakatsugawa (1966). Fed. Proc. 25, 1187.

Konno, N. and T. Koseki (1967). Folia Endocrinol. Jap. 42, 1227. (In Japanese).

Konno, N. (1974). ibid. 50, 711. (In Japanese).

Konno, N. (1976). Endocrinol. Japon. 23, 313.

Nagata, H., T. Izumiyama, K. Kawata, S. Kono, Y. Yukimura, M. Towata, T. Aizawa and T. Yamada (1976). J. Clin. Endocrinol. Metab. 43, 1153. 
Odell, W. D., J. F. Wilber and R. D. Utiger (1967). Recent Prog. Hormone Res. 23, 47.

Oshiba, S. (1957). Jap. J. Physiol. 7, 335.

Rabello, M. M., P. J. Snyder and R. D. Utiger (1974). J. Clin. Endocrinol. Metab. 39. 571.

Rastogi, G. K. and R. C. Sawhney (1976). Metabolism 25, 903.

Sawin, G. T. and J. M. Hershman (1976). J. Clin. Endocrinol. Metab. 42, 809.

Smals, A. G. H., H. A. Ross and P. W. C. Kloppenborg (1977). ibid. 44, 998.

Smith, R. E. and D. J. Hoijer (1962). Physiol. Rev. 42,60 .
Snyder, P. J. and R. D. Utiger (1972). J. Clin. Invest. 51, 2077.

Snyder P. J. and R. D. Utiger (1973). ibid. 52, 2305.

Tal, E., R. Chayoth, U. Zor, G. Goldhaber and A. Zerachie (1976). Acta Endocrinol. (Kbh.) 83, 99.

Vagenakis, A., B. Rapoport, F. Azizi, G. I. Portnay, L. E. Braverman and S. H. Ingbar (1974) J. Clin. nvest. 54, 913.

Watanabe, G., M. Uematsu and K. Morii (1963). J. Clin. Endocrinol. Metab. 23, 383.

Yamada, T., A. Kajihara, T. Onaya, I. Kobayashi, Y. Takemura and K. Shichijo (1965). Endocrino$\log y 77,968$. 